\title{
Mechanisms and Clinical Trials of Hepatocellular Carcinoma Immunotherapy
}

\author{
Shao-Li Huang ${ }^{1,2,3 t}$, Yu-Ming Wang ${ }^{4,5 t}$, Quan-Yue Wang ${ }^{6 \dagger}$, Guang-Gui Feng ${ }^{1,3}$, \\ Fu-Qing Wu ${ }^{1,3}$, Liu-Ming Yang ${ }^{2,3,7 *}, X_{i-H e}$ Zhang $^{2,3 *}$ and Hong-Wu Xin ${ }^{8,9 *}$
}

OPEN ACCESS

Edited by:

Kecheng Zhou,

Anhui Medical University, China

Reviewed by:

Martin Perez-Santos,

Benemérita Universidad Autónoma

de Puebla, Mexico

Ankur Sharma,

Harry Perkins Institute of Medical

Research, Australia

*Correspondence:

Liu-Ming Yang

yw13813198@163.com

Xi-He Zhang

hljsnjx@163.com

Hong-Wu Xin

hongwu_xin@126.com

${ }^{\dagger}$ These authors have contributed equally to this work

Specialty section:

This article was submitted to Cancer Genetics and Oncogenomics,

a section of the journal

Frontiers in Genetics

Received: 06 April 2021

Accepted: 08 June 2021

Published: 08 July 2021

Citation:

Huang S-L, Wang $Y-M$,

Wang $Q-Y$, Feng $G-G, W u F-Q$,

Yang $L-M$, Zhang $X-H$ and $X$ in $H-W$

(2021) Mechanisms and Clinical Trials

of Hepatocellular Carcinoma

Immunotherapy.

Front. Genet. 12:691391.

doi: 10.3389/fgene.2021.691391
' Department of Clinical Laboratory, Lianjiang People's Hospital, Zhanjiang, China, ${ }^{2}$ Doctoral Scientific Research Center, Lianjiang People's Hospital, Zhanjiang, China, ${ }^{3}$ Guangdong Medical University Affiliated Lianjiang People's Hospital, Zhanjiang, China, ${ }^{4}$ Department of Spinal and Neural Functional Reconstruction, Beijing Bo'ai Hospital, China Rehabilitation Research Center, Beijing, China, ${ }^{5}$ School of Rehabilitation Medicine, Capital Medical University, Beijing, China, ${ }^{6}$ Qinghai Institute of Health Sciences, Xining, China, ${ }^{7}$ Department of Gastroenterology and Hepatology, Lianiiang People's Hospital, Zhanjiang, China, ${ }^{8}$ Laboratory of Oncology, Center for Molecular Medicine, School of Basic Medicine, Faculty of Medicine, Yangtze University, Jingzhou, China, ${ }^{9}$ Department of Biochemistry and Molecular Biology, School of Basic Medicine, Faculty of Medicine, Yangtze University, Jingzhou, China

Hepatocellular carcinoma ( $\mathrm{HCC}$ ), one of the most common and lethal tumors worldwide, is usually not diagnosed until the disease is advanced, which results in ineffective intervention and unfavorable prognosis. Small molecule targeted drugs of HCC, such as sorafenib, provided only about 2.8 months of survival benefit, partially due to cancer stem cell resistance. There is an urgent need for the development of new treatment strategies for HCC. Tumor immunotherapies, including immune check point inhibitors, chimeric antigen receptor T cells (CAR-T) and bispecific antibodies (BsAb), have shown significant potential. It is known that the expression level of glypican-3 (GPC3) was significantly increased in HCC compared with normal liver tissues. A bispecific antibody (GPC3-S-Fabs) was reported to recruit NK cells to target GPC3 positive cancer cells. Besides, bispecific T-cell Engagers (BiTE), including GPC3/CD3, an aptamer TLS11a/CD3 and EpCAM/CD3, were recently reported to efficiently eliminate HCC cells. It is known that immune checkpoint proteins programmed death-1 (PD-1) binding by programmed cell death-ligand 1 (PD-L1) activates immune checkpoints of T cells. AntiPD-1 antibody was reported to suppress HCC progression. Furthermore, GPC3-based HCC immunotherapy has been shown to be a curative approach to prolong the survival time of patients with HCC in clinically trials. Besides, the vascular endothelial growth factor (VEGF) inhibitor may inhibit the migration, invasion and angiogenesis of HCC. Here we review the cutting-edge progresses on mechanisms and clinical trials of HCC immunotherapy, which may have significant implication in our understanding of HCC and its immunotherapy.

Keywords: hepatocellular carcinoma, immunotherapy, bispecific T-cell Engagers, bispecific antibody, aptamer, vascular endothelial growth factor (VEGF) 


\section{INTRODUCTION}

Hepatocellular carcinoma (HCC) is caused by genetic and epigenetic changes of tissue stem cells and progressed through the interaction between cancer cells and tumor microenvironment (Hari et al., 2011; Xin et al., 2012, 2016; Xin et al., 2013; Xin H. W. et al., 2013; Ellison et al., 2017; Liu et al., 2017). Infection with hepatitis $\mathrm{B}$ virus and hepatitis $\mathrm{C}$ virus is the major cause of chronic hepatitis and HCC. Besides, aflatoxin, smoking, obesity, excessive alcoholic drink and hyperlipidemia also play significant roles in the process of HCC. Consequently, high incidence and mortality rate have made HCC to be one of the deadliest cancers and severe health issue (Guo et al., 2018; Hu et al., 2018; Jin et al., 2018).

Hepatocellular carcinoma progresses with no clinical symptoms in the early stage, whereas clinical symptoms become obvious in the advanced stage, leading to ineffective intervention and poor prognosis. Current prevailing medical treatments for HCC, including surgical ablation, chemotherapy (including chemoembolization), radiotherapy (including proton beam therapy), targeted therapy, and virotherapy, can generally achieve limited overall survival time (Xiang et al., 2015). The effective approach for the treatment of HCC is excision of cancerous tissue in early phases. The target selectivity of radiotherapy for HCC patients is not sensitive enough (Zhu et al., 1998). Sorafenib, an multi-kinase inhibitor, is one of the recommended medicine for patients with advanced HCC and has been shown to improve the overall survival, but with various side effects such as diarrhea, fatigue, and skin reaction of hand and foot. Furthermore, the drug resistance is the major issue for the treatment of HCC patients at advanced stages. Only $30 \%$ of HCC patients obtain survival benefits from sorafenib (Su et al., 2018). Other multikinase inhibitors such as lenvatinib and regorafenib have also been approved for the treatment of HCC patients. Lenvatinib is approved as the first-line therapy and regorafenib, which is an inhibitor closely associated with sorafenib, is approved as the second-line therapy. However, lenvatinib and regorafenib have limited survival benefit for the patients with HCC (Ruiz De Galarreta et al., 2019). In addition, cancer stem cells (CSCs) display cellular hierarchies with selfrenewing tumor-initiating cells at the apex and are believed to cause drug resistance of tumors (Yamashita and Wang, 2013; De Angelis et al., 2019). Studies have demonstrated that ten of label-retaining cancer cells (LRCC) of human HCC are able to initiate tumors. Unfortunately, LRCC is relatively resistant to sorafenib and metformin (a reported potential drug against CSC) (Xin H. W. et al., 2013).

Therefore, there is an urgent need for effective therapeutic strategies for HCC. Recently, tumor immunotherapies, including immune check point inhibitors, chimeric antigen receptor $\mathrm{T}$ cells (CAR-Ts), and bispecific antibodies (BsAb), have shown great clinical benefit for HCC patients. BiTE, a form of BsAb that binds CD3 and tumor-associated antigens (TAA) (Frankel and Baeuerle, 2013; Sedykh et al., 2018), capable to recruit T cells to cancer cells for elimination (Oberst et al., 2014). The specific killing of the cancer cells by BiTE was mediated by concomitant cytokine release and HCC cell lysis (Figure 1).
Here we review recent research progresses in the mechanisms and clinical trials of HCC immunotherapies against glypican-3 (GPC3), epithelial cell adhesion molecule (EpCAM) and TLS11a, and programmed death-1 (PD-1).

\section{MECHANISMS OF HCC IMMUNOTHERAPY}

\section{GPC3-Based Immunotherapy: GPC3/NK BsAb, GPC3/BiTE, GPC3/CAR-Ts and GPC3 Peptide Vaccine}

Glypican-3 belongs to heparin sulfate (HS) protein polysaccharide family and anchors to cell surface by glycosylphosphatidylinositol (GPI) (Filmus and Selleck, 2001; Sun et al., 2017). Glypicans interact with growth factors and play significant roles in cell proliferation, differentiation, and migration (Filmus and Selleck, 2001). The growth of HCC cells can be stimulated by GPC3 by the means of typical Wnt signaling pathway (Figure 1; Capurro et al., 2005; Chen et al., 2018). A frizzled-like cysteine-rich domain of GPC3 can regulate Wnt binding and mediate the growth of mouse HCC tumors (Li et al., 2019). Besides, GPC3 can negatively regulate bone morphogenesis protein 7 (BMP-7) to modulate cell proliferation (Midorikawa et al., 2003; Chen et al., 2018). Overexpression of GPC3 in the cell membrane can induce M2-polarized tumorassociated macrophages to enter human HCC tissues that may stimulate the progression and metastasis of HCC (Takai et al., 2009). GPC3 is absent in normal and benign tissues, whereas expresses in human embryo and many kinds of neoplastic cells such as HCC, melanoma, and squamous non-small cell lung cancer (Sun et al., 2017). GPC3 accounts for the initiation and progression of HCC (Llovet et al., 2006; Baumhoer et al., 2008). A meta-analysis found that GPC3 was highly expressed in high-grade and advanced stage HCC cells, and tumor vascular cells in HCC (Liu H. et al., 2018). The expression of GPC3 is relate with tumor size of HCC, which suggest that GPC3 may potentially become an early diagnosis biomarker of HCC. Research has suggested that the accuracy and sensitivity for early diagnosis of HCC by using combined serum GPC3 and alpha fetoprotein (AFP) were better than AFP alone. AFP is a glycoprotein, which is mainly synthesized by fetal liver cells and yolk sac. Elevated AFP in adulthood is considered as a pathological condition. AFP Levels are elevated in many diseases including HCC, stomach cancer, yolk sac tumors and so on. Besides, more than $70 \%$ liver cancer patients show positive AFP. Therefore, serum AFP is considered as the standard biomarker for clinical diagnosis of liver cancer. A study showed that AFP stimulated the progression of HCC by inhibiting human antigen $\mathrm{R}$ (HuR)-mediated Fas/FADD (Fas-associating protein with a novel death domain) apoptotic pathway (Chen et al., 2020). The diagnosis by AFP or GPC3 could be improved by combining GPC3 and AFP (El-Saadany et al., 2018). Another research showed that patients with high preoperative plasma level of GPC3 was more likely to undergo postoperative recurrence (Ofuji et al., 2017). Furthermore, it was shown that GPC3 


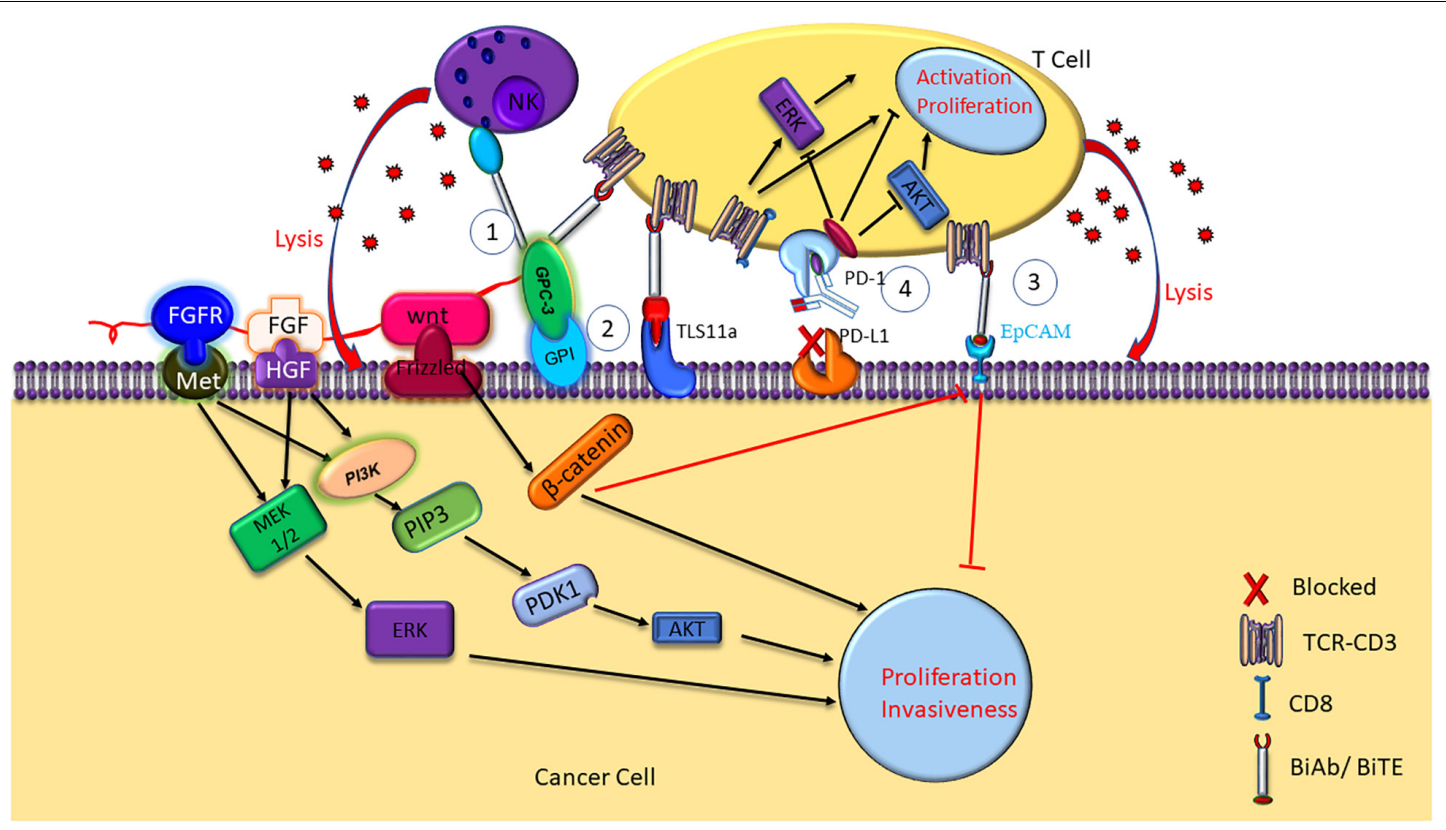

FIGURE 1 | Mechanisms of HCC immunotherapy targeting GPC3, TLS11a, EpCAM, and PD-1. NK BsAb and BiTE mediate T cell immunotherapy targeting GPC3 + HCC. GPC3 promotes HCC growth by upregulating the Wnt- $\beta$-catenin and FGF signaling. Aptamer bispecific antibody TLS11a/CD3 can mediate T cell immunotherapy by binding to both the HCC cancer cell and the T cell, inducing T cell cytotoxicity and proinflammatory cytokine release, such as IL-2, IL-6, IL-10, TNF- $\alpha$, and IFN- $\gamma$. BiTE mediates T cell immunotherapy targeting EpCAM + HCC. Antibodies against PD-1 or PD-L1/2 on the cell surface inhibit the immune check point, and block the immune escape in HCC.

promotes HCC growth by upregulating the expression of Wnt as well as insulin-like growth factors (Cheng et al., 2008). GPC3 was found to be significantly related to HCC tumorigenesis through Wnt-5,6,7, Yap8, transforming growth factor- $\beta 29$ (TGF- $\beta 29$ ), and human growth factor 10 (HGF10) signaling (Ho and Kim, 2011). Most importantly, apoptosis was induced in HCC cell lines when GPC3 was silenced, which suggest that GPC3 play an important role in HCC carcinogenesis (Liu et al., 2012).

The high expression of GPC3 preferentially in HCC suggest that it can be used as a target for immunotherapy and the GPC3 expression on the surface of HCC cells makes it a good target for antibody therapy (Wang Y. et al., 2018). GPC3-binding antibodies have indeed been developed for immunotherapies of HCC, such as unmodified antibodies, immunotoxin bound antibodies, GPC3/NK BsAb, BiTE, and other BsAb (Lipovšek et al., 2018). GPC3-S-Fab, is an antibody Fab fragment based $\mathrm{BiAb}$, and recruits NK cells to eliminate GPC3 positive cancer cells by linking the Fab of anti-GPC3 antibody to anti-CD16 single domain antibody (Table $\mathbf{1}$ and Figure 1). In another $\mathrm{BiAb}$, the GPC3/CD3 BiTE was also developed to recruit cytotoxic T lymphocyte (CTL) cells for clearance of GPC3 ${ }^{+}$HCC cells (Lampen et al., 2018; Table 1 and Figure 1). The therapeutic effect of BiTE depends on the concentration of GPC3/CD3 BiTE and the expression level of GPC3 on target cells. It has been demonstrated that the effect of BiTE is strongly GPC3dependent in vitro and in vivo (Bi et al., 2017). In addition, GPC3-targeted CAR-T cells with CD28 co-stimulatory domain were also developed and showed anti-HCC effect in xenograft tumors (Guo et al., 2018). Furthermore, GPC3 peptide vaccine was also demonstrated to reduce recurrence rate of HCC patients (Sawada et al., 2016).

\section{TLS11a Aptamer}

Aptamers are ssDNA or ssRNA that are selected via library screening using SELEX (systematic evolution of ligands by exponential enrichment). They can combine with various targets such as small dyes, proteins, peptides, the whole cells, tissues and toxins, as it can fold into a variety of forms of threedimensional (3D) structure (Kumar Kulabhusan et al., 2020). An aptamer bispecific antibody TLS11a/CD3 (Sulfo-SMCC, Thermo Scientific Co.) has been constructed by combining TLS11a-SH or S2.2-SH with the anti-CD3-NH2 at $4^{\circ} \mathrm{C}$ for $24 \mathrm{~h}$, and the noncrosslinked aptamers of the reaction mixture was removed by centrifuging at $14000 \mathrm{rpm}$ for $10 \mathrm{~min}$. TLS11a/CD3 can bind to both HCC cells and T cells by aptamer TLS11a and anti-CD3 single chain variable region, respectively (Figure 1). TLS11a/CD3 was capable to guide T cells to target and kill HCC cells with high specificity and affinity and was shown to repress the proliferation of HCC $\mathrm{H} 22$ cells in vitro and prolong mouse survival time by inhibiting the progression of xenograft tumor in vivo (Table 2). $\mathrm{T}$ cell proliferation and the production of multiple cytokines, such as interleukin-2 (IL-2), IL-6, IL-10, tumor necrosis factor-alpha $(\mathrm{TNF}-\alpha)$, and interferon-gamma (IFN- $\gamma$ ), were significantly higher in the $\mathrm{T}$ cells $+\mathrm{H} 22+\mathrm{TL} 11 \mathrm{a} / \mathrm{CD} 3+$ group than in the control group, which also supported the anti-tumor effect of TL11a/CD3. Compared to other lower concentration groups, TLS11a/CD3 (20 $\mu \mathrm{g})$ group had the best effect in tumor inhibition and prolonging survival on the hepatoma xenograft 
model. The tumor inhibition efficacy of TLS11a/CD3 was found to be dose dependent (Hu Z. et al., 2018).

\section{EpCAM-BiTE}

Epithelial cell adhesion molecule is a transmembrane glycoprotein and its expression was increased in HCC tissues compared with adjacent normal liver tissues (Schmelzer et al., 2006). EpCAM expression in HCC was positively correlated with chemotherapy resistance and recurrence ( $\mathrm{Li} \mathrm{Y}$. et al., 2016). Importantly, EpCAM-positive cells showed characteristics of $\mathrm{CSC}$ and $\mathrm{EpCAM}^{+} \mathrm{AFP}^{+} \mathrm{HCC}$ was associated with poor prognosis. High tumorigenicity, high colony formation and low differentiation potency were found in EpCAM-positive HCC cell line PLC/PRF/5 and the proliferation and invasiveness of HCC cells were significantly reduced when EpCAM expression was downregulated (Kimura et al., 2014). EpCAM was found to be one of the Wnt- $\beta$-catenin signaling direct transcription target in normal human hepatocytes and hepatoma cells (Yamashita et al., 2007). CSC enrichment promotes the HCC tumorigenesis by Wnt- $\beta$-catenin signaling (Pandit et al., 2018). In response to Wnt- $\beta$-catenin signaling antagonists (natural compounds PKF118-310, PKF115-584, and CGP049090) (Lepourcelet et al., 2004), EpCAM expression was significantly decreased, suggesting Wnt- $\beta$-catenin signaling promoted EpCAM expression (Yamashita et al., 2007). A Study found that liver cancer CSCs with EpCAM-high upregulated the expression of carcinoembryonic antigen-related adhesion molecule 1 (CEACAM1) to resist the natural killer (NK) cell mediated cytotoxicity (Park et al., 2020). Moreover, EpCAM positive circulatory stem-like cells were associated with unfavorable prognosis of HCC patients who underwent radical resection. Therefore, EpCAM is considered as a CSC marker and a potential target for immunotherapy of HCC (Yamashita et al., 2007, 2009).

An anti-EpCAM BiTE, 1H8/CD3, has been constructed and was shown to inhibit the growth of xenograft tumors from HCC cell lines Hep3B and Huh-7 in vivo (Figure 1). Xenografts from the $1 \mathrm{H} 8 / \mathrm{CD} 3$ treated mice showed decreased expression of majority CSC markers. However, the function of $1 \mathrm{H} 8 / \mathrm{CD} 3$ was inhibited when galectin-1 (Gal-1) was overexpressed in HCC tumors (Zhang et al., 2014).

\section{PD-1 Immune Check Point Inhibitor}

Programmed death-1 is a transmembrane receptor that belongs to the immunoglobulin super family (IgSF) (Ohaegbulam et al., 2015) and is mainly expressed on the surface of $\mathrm{CD}^{+} \mathrm{T}$ lymphocytes and NK cells, and functions as an inhibitory receptor (Gros et al., 2014). A study showed that both T-cell immunoglobulin domain and mucin domain containing molecule-3 (TIM-3) and PD-1 were highly expressed on the infiltrating lymphocytes of hepatitis B-related HCC tumors and adjacent tissues ( $\mathrm{Li} \mathrm{Z}$. et al., 2016). PD-L1/2 on the surface of cancer cells inhibits activation and proliferation of $\mathrm{T}$ cell, resulting in cancer cell escape from the immune response (Zou et al., 2016). Besides, a study showed that MYC (one of the frequently altered ongenes in patients with HCC) in the tumor suppressor $\mathrm{p} 53-/-\mathrm{HCC}$ upregulated $\beta$-catenin signaling to promote immune escape. More importantly, the activation of $\beta$-catenin repressed the recruitment of DCs, accelerated

TABLE 1 | Features of the tumor associated antigens of HCC.

\begin{tabular}{|c|c|c|c|c|}
\hline & GPC3 & TLS11a target & EpCAM & PD-1 \\
\hline $\begin{array}{l}\text { Expression in normal } \\
\text { tissues }\end{array}$ & Low & None & Low & T cells \\
\hline Expression in HCC tumors & High in about $70 \%$ & High & High & PD-L1/2 high \\
\hline Function & $\begin{array}{l}\text { Cancer cell proliferation, } \\
\text { migration, metastasis }\end{array}$ & $\begin{array}{l}\text { TLS11a-BiTE Inhibits HCC } \\
\text { cells Hep3B and Huh-7 }\end{array}$ & A CSC marker & Inhibiting T cells \\
\hline $\begin{array}{l}\text { McAb scFv or gRNA } \\
\text { sequence }\end{array}$ & Not found & $\begin{array}{l}\text { 5-ACA GCATCC CCA TGT } \\
\text { GAA } \\
\text { CAATCGCATTGTGATTGTTA } \\
\text { CGGTICCGCCTCATGGACG } \\
\text { TGCTGTIIIIIT-SH-3 }\end{array}$ & Not found & $\begin{array}{l}\text { PD-1-gRNA-1: } \\
\text { GTCTGGGCGG } \\
\text { TGCTACAACT; } \\
\text { PD-1-RNA-2: } \\
\text { GGCCAGGATG } \\
\text { GTTCTTAGGT. }\end{array}$ \\
\hline Ref & Wang Y. et al., 2018 & Hu Z. et al., 2018 & Zhang et al., 2014 & Guo et al., 2018 \\
\hline
\end{tabular}

TABLE 2 | BiAb-based immunotherapy against the tumor associated antigens of HCC.

\begin{tabular}{|c|c|c|c|c|c|}
\hline Target & Drug & Methods & Effect & Adverse effect & Ref \\
\hline GPC3 + HCC & $\begin{array}{l}\text { GPC3/CD16 GPC3- } \\
\text { S-Fab BiAb/BiTE }\end{array}$ & Cell culture, xenograft & Effective against tumors. & Not found & Wang Y. et al., 2018 \\
\hline $\begin{array}{l}\mathrm{H} 22 \text { or BNL } \\
\text { CL2 HCC }\end{array}$ & $\begin{array}{l}\text { TLS11a aptamer/ } \\
\text { CD3 BiTE }\end{array}$ & Mouse xenograft & Mediated effective tumor lysis. & $\begin{array}{l}\text { Poor stability, } \\
\text { immunogenicity and high } \\
\text { cost production }\end{array}$ & Hu Z. et al., 2018 \\
\hline EpCAM + HCC & $\begin{array}{l}\text { anti-EpCAM BiTE } \\
\text { (1H8/CD3) }\end{array}$ & $\begin{array}{l}\text { Hep3B, Huh-7, mouse } \\
\text { xenograft }\end{array}$ & $\begin{array}{l}\text { Significantly suppressed tumor } \\
\text { growth and CSC marker } \\
\text { expression. }\end{array}$ & $\begin{array}{l}\text { Gal-1 may be conducive } \\
\text { to resistance to } \\
1 \mathrm{H} 8 / \mathrm{CD} 3 \text {-induced lysis. }\end{array}$ & Zhang et al., 2014 \\
\hline
\end{tabular}


the immune escape and caused the resistance of the antiPD-1 therapy (Ruiz De Galarreta et al., 2019). In addition, the up-regulation of Toll-like receptor 9 (TLR9) by PD-L1 induces immune escape in HCC (Zhou et al., 2020). Researchers demonstrated that blocking PD-1 or PD-L1 induce activation of $\mathrm{T}$ cells with increased IFN- $\gamma$ release and $\mathrm{T}$ cell proliferation (Figure 1). PD-1 inhibits the consumption of oxygen, represses glutaminolysis and glycolysis of the activated $\mathrm{T}$ cells and reshapes their metabolism appropriately to change $\mathrm{T}$ cell differentiation. Besides, the PD-1 pathway induces PD-L1 by proinflammatory signal to inhibit the effector $\mathrm{T}$ cells and maintain self-tolerance. In addition, low levels of PD-1 expression are needed to suppress the expansion of T-cell as well as the IFN- $\gamma$, IL-2, and TNF- $\alpha$ production (Boussiotis, 2016). High PD-L1 expression in HCC tumors were an index of unfavorable prognosis for HCC patients who underwent surgical resection (Wang et al., 2017) and the level of serum PD-L1 is also positively correlated with HCC stages and mortality risk (Finkelmeier et al., 2016).

$\mathrm{PD}-1^{+}$tumor infiltrating lymphocytes were an effective prognostic biomarker to predict the survival benefit for HCC patients who underwent the immunotherapy with cytokine induced killer (CIK) (Chang et al., 2018). PD-1 knockout was found to significantly enhance the anti-HCC efficacy of CIK cells. Study have shown that the combination of human telomerase reverse transcriptase (hTERT) transduction and PD1 knockout of CIK cells improved the anti-HCC efficacy of CIK cells (Huang et al., 2018). In addition, PD-1 disruption was found to enhance the anti-HCC effect of GPC3 CAR$\mathrm{T}$ cells in NOD-scid-IL-2R $\gamma /-/-$ (NSG) mice in vivo (Guo et al., 2018). Furthermore, Nivolumab, a complete human IgG4 monoclonal antibody against PD-1, has been approved by the United States Food and Drug Administration (FDA) for late stage melanoma and metastatic non-small cell lung cancer. Research have showed that Nivolumab also get an acceptable effectiveness in HCC patients and may become an alternative therapy for HCC patients who have failed routine treatments (Feng et al., 2017). Besides, pembrolizumab, another FDA approved anti-PD1 antibody, also demonstrated that the anti-tumor activity and safety in previously treated patients with HCC in clinical trials (Finn et al., 2020a).

\section{VEGF}

The vascular endothelial growth factor (VEGF), a signaling ligand released by epithelial cells, is an important positive angiogenesis regulator (Yang et al., 2014; Zhang et al., 2020) and VEGF signaling plays a significant role in inhibiting the apoptosis and promoting proliferation in tumor cells (Liu et al., 2016). Highly vascularized tissue of adult liver is an important feature for its function, each liver cell is lined with sinusoidal endothelial cells (SEC) on both sides. It was reported that SEC fenestration was regulated by hepatocytemediated VEGF signaling during liver angiogenesis (Carpenter et al., 2005; Sharma et al., 2020). In addition, a study demonstrated that HCC shared the immune microenvironment and stromal microenvironment with fetal liver and suggested that VEGF and $\mathrm{NOTCH}$ signaling play important role in the maintenance of onco-fetal ecosystem. Importantly, it was shown that VEGF was also related with the metastasis and recurrence of HCC (Minata et al., 2013). Moreover, the downregulation of exosmosis tumor C-Type Lectin Domain Family 3 Member B (CLEC3B) could accelerate the angiogenesis and metastasis of HCC by VEGF and AMP-activated protein kinase (AMPK) pathways (Dai et al., 2019). Research has indicated that tumor immune microenvironment and VEGF signaling pathway in HCC patients are synergistically activated, which suggests a prominent mechanism of combined therapy including immune checkpoint blockades (ICBs) and anti-VEGF drugs (Liu et al., 2020). Atezolizumab and bevacizumab are PD-L1 inhibitor and VEGF inhibitor, respectively, and a recent study of IMBrave150 trial indicated that comparing with sorafenib, atezolizumab in combination with bevacizumab improved overall response rate, overall survival and progression-free survival dramatically in patients with unresectable HCC (Finn et al., 2020b; Hack et al., 2020). Furthermore, FDA approved the combination of atezolizumab with bevacizumab as a new firstline treatment for advanced or unresectable HCC patients (Liu et al., 2020). The IMBrave150 trial also suggested that double blockade of PD-L1/VEGF can effectively reduce the recurrence of HCC by creating a more immunologically advantageous microenvironment (Hack et al., 2020). Apatinib is a specific inhibitor of VEGF-receptor 2 (VEGFR2) (Tian et al., 2011) and a recent study showed that apatinib blocked the VEGF and PI3K/AKT signaling pathways to inhibit the migration, invasion and angiogenesis of HCC cells (Song et al., 2021). Besides, lots of clinical trials involving as the VEGFR2 inhibitor apatinib in HCC are ongoing as showed in Table 3, most of which are exploring the combination of apatinib with other drugs or therapies to treat HCC to extend the survival time or to reduce the adverse side-effects. Furthermore, ramucirumab, another inhibitor of VEGF-receptor 2, was showed to have survival benefit in an age subgroup with safety tolerance, which supported its use in late stage HCC with elevated AFP, regardless of age (Kudo et al., 2020). Therefore, as a second line drug, ramucirumab was approved by FDA for the advanced HCC patients with $\mathrm{AFP} \geq 400 \mathrm{ng} / \mathrm{mL}$ after sorafenib treatment (De Luca et al., 2020).

\section{CLINICAL TRIALS OF HCC IMMUNOTHERAPY}

A series of anti-GPC3 chimeric antigen receptor modified T cells (GPC3-CAR-T) had being tested in phase I/II trials (Table 4). In addition, a humanized anti-human GPC3 antibody, GC33, was tested in clinical trials to examine the pharmacokinetics, dosage and duration of treatment, safety and tolerability, and antitumor activity in GPC3 high expression hepatoma cells (Tables 4, 5). The adverse reactions of GC33 were mainly fatigue (50\%), constipation (35\%), headache (35\%), and hyponatremia (35\%), most of which were grade 1 or 2 . The number of peripheric NK cells was decreased after GC33 treatment, but no increased incidence of infection was observed. These research have showed that GC33 had potential antitumor activity in patients with high GPC3 expression HCC tumors and provided a preliminary 
TABLE 3 | Ongoing clinical trials involving Apatinib (VEGFR2 inhibitor) in HCC.

\begin{tabular}{|c|c|c|c|c|c|}
\hline Name & Trail ID & Phase & Study population & Intervention & Status \\
\hline Apatinib & NCT03046979 & $\|$ & Advanced HCC patients & Apatinib & Unknown \\
\hline Apatinib and TACE & NCT03066557 & $\begin{array}{l}\text { Not } \\
\text { Applicable }\end{array}$ & HCC patients & TACE and Apatinib & Unknown \\
\hline Apatinib & NCT01192971 & $\|$ & Advanced HCC patients & Apatinib & Completed \\
\hline Apatinib & NCT02727309 & $|/| \mid$ & Advanced HCC patients & Apatinib after TACE & Unknown \\
\hline Apatinib and Camrelizumab & NCT04521153 & $\begin{array}{l}\text { Not } \\
\text { Applicable }\end{array}$ & Resectable HCC patients & $\begin{array}{l}\text { Camrelizumab and Apatinib } \\
\text { Mesylate Procedure: TACE } \\
\text { treatment and radical surgery }\end{array}$ & Recruiting \\
\hline SHR-1210 and Apatinib & NCT04297202 & $\|$ & HCC patients & $\begin{array}{l}\text { Apatinib combined with } \\
\text { SHR-1210 injection }\end{array}$ & Recruiting \\
\hline Apatinib and Capecitabine & NCT03114085 & $\|$ & Advanced HCC patients & $\begin{array}{l}\text { Capecitabine and Apatinib } \\
\text { compared with Apatinib }\end{array}$ & Unknown \\
\hline $\begin{array}{l}\text { Cryoablation, } \\
\text { Camrelizumab and Apatinib }\end{array}$ & NCT04724226 & $\|$ & Advanced HCC patients & $\begin{array}{l}\text { Cryoablation, Camrelizumab, } \\
\text { Apatinib }\end{array}$ & Not yet recruiting \\
\hline SHR-1210 Plus Apatinib & NCT04014101 & $\|$ & Advanced stage HCC & SHR-1210 and Apatinib & Recruiting \\
\hline Apatinib & NCT02772029 & $|/| 1$ & $\begin{array}{l}\text { Advanced HCC Patients After } \\
\text { First-line Treatment Failure }\end{array}$ & Apatinib Mesylate Tablets & Unknown \\
\hline SHR-1210 Plus Apatinib & NCT03722875 & $\begin{array}{l}\text { Not } \\
\text { Applicable }\end{array}$ & $\begin{array}{l}\text { BCLC B and C stage HCC after } \\
\text { surgery }\end{array}$ & SHR-1210 and Apatinib & Unknown \\
\hline $\begin{array}{l}\text { Sintilimab, Apatinib and } \\
\text { Capecitabine }\end{array}$ & NCT04411706 & $\|$ & Advanced HCC patients & $\begin{array}{l}\text { Sintilimab Combined With } \\
\text { Apatinib and Capecitabine }\end{array}$ & Recruiting \\
\hline Apatinib & NCT03511703 & $\|$ & Advanced HCC & $\begin{array}{l}\text { Postoperative adjuvant Apatinib } \\
\text { vs. TACE, chemotherapy } \\
\text { drugs + iodized }\end{array}$ & Unknown \\
\hline Apatinib and Camrelizumab & NCT04191889 & $\|$ & C-staged HCC patients & $\begin{array}{l}\text { Hepatic Arterial Infusion with } \\
\text { Apatinib and Camrelizumab }\end{array}$ & Recruiting \\
\hline Apatinib plus radiotherapy & NCT03520257 & $\|$ & $\begin{array}{l}\text { HCC patients with BCLC-C } \\
\text { stage I and II portal vein tumor } \\
\text { thrombus }\end{array}$ & $\begin{array}{l}\text { Apatinib plus radiotherapy vs. } \\
\text { Apatinib }\end{array}$ & Unknown \\
\hline $\begin{array}{l}\text { Camrelizumab, Apatinib } \\
\text { and Oxaliplatin }\end{array}$ & NCT04850040 & $\|$ & $\begin{array}{l}\text { Patients with potentially } \\
\text { resectable HCC }\end{array}$ & $\begin{array}{l}\text { Apatinib Mesylate, } \\
\text { Camrelizumab and Oxaliplatin }\end{array}$ & Not yet recruiting \\
\hline Camrelizumab and Apatinib & NCT04701060 & $\|$ & $\begin{array}{l}\text { Resectable primary HCC } \\
\text { patients }\end{array}$ & $\begin{array}{l}\text { Camrelizumab Combined With } \\
\text { Apatinib }\end{array}$ & Recruiting \\
\hline $\begin{array}{l}\text { Camrelizumab, Apatinib } \\
\text { and chemotherapy }\end{array}$ & NCT04479527 & $\|$ & Advanced HCC patients & $\begin{array}{l}\text { (CTACE or } \\
\text { DEB-TACE + FOLFOX regimen } \\
\text { HAIC) combined with } \\
\text { Camrelizumab and Apatinib }\end{array}$ & Not yet recruiting \\
\hline Apatinib and SHR-1210 & NCT02942329 & $\mid / I$ & HCC or gastric cancer patients & Apatinib and SHR-1210 & Unknown \\
\hline Camrelizumab and Apatinib & NCT04826406 & $\|$ & $\begin{array}{l}\text { HCC patients previously treated } \\
\text { with immune checkpoint } \\
\text { inhibitors }\end{array}$ & $\begin{array}{l}\text { Camrelizumab combined with } \\
\text { Apatinib regimen }\end{array}$ & Recruiting \\
\hline SHR-1210 and Apatinib & NCT03793725 & $\|$ & Patients with unresectable HCC & $\begin{array}{l}\text { SHR1210 combined with } \\
\text { Apatinib }\end{array}$ & Unknown \\
\hline Apatinib and SHR-1210 & NCT03839550 & $\|$ & $\begin{array}{l}\text { HCC patients with high risk of } \\
\text { recurrence after radical } \\
\text { resection }\end{array}$ & $\begin{array}{l}\text { Hepatic Arterial Infusion (HAl) of } \\
\text { Apatinib Mesylate + PD-1 } \\
\text { antibody SHR-1210. }\end{array}$ & Not yet recruiting \\
\hline $\begin{array}{l}\text { Camrelizumab Plus } \\
\text { Apatinib }\end{array}$ & NCT04639180 & III & $\begin{array}{l}\text { Patients with HCC at high risk } \\
\text { of recurrence after surgical }\end{array}$ & $\begin{array}{l}\text { Camrelizumab plus Apatinib as } \\
\text { adjuvant therapy in HCC }\end{array}$ & Not yet recruiting \\
\hline $\begin{array}{l}\text { M1-c6v1, SHR-1210 and } \\
\text { Apatinib }\end{array}$ & NCT04665362 & 1 & HCC patients & $\begin{array}{l}\text { Recombinant oncolytic virus } \\
\text { M1-c6v1, anti-PD-1 antibody } \\
\text { SHR-1210, and Apatinib }\end{array}$ & Not yet recruiting \\
\hline Camrelizumab plus Apatinib & NCT04035876 & $|/| \mid$ & $\begin{array}{l}\text { Downstaging/bridging of } \mathrm{HCC} \\
\text { patients before liver transplant }\end{array}$ & $\begin{array}{l}\text { Camrelizumab (SHR-1210) and } \\
\text { Apatinib combination }\end{array}$ & Recruiting \\
\hline Radiotherapy, and Apatinib & NCT03732105 & $\|$ & $\begin{array}{l}\text { HCC patients received curative } \\
\text { resection with microvascular } \\
\text { invasion }\end{array}$ & $\begin{array}{l}\text { Radiotherapy, Apatinib, or } \\
\text { radiotherapy + Apatinib }\end{array}$ & Not yet recruiting \\
\hline $\begin{array}{l}\text { TACE, Camrelizumab and } \\
\text { Apatinib }\end{array}$ & NCT04559607 & $\begin{array}{l}\text { Not } \\
\text { Applicable }\end{array}$ & $\begin{array}{l}\text { Intermediate and advanced } \\
\text { HCC patients }\end{array}$ & $\begin{array}{l}\text { TACE combined with } \\
\text { Camrelizumab and Apatinib }\end{array}$ & Recruiting \\
\hline
\end{tabular}


TABLE 3 | Continued

\begin{tabular}{|c|c|c|c|c|c|}
\hline Name & Trail ID & Phase & Study population & Intervention & Status \\
\hline SHR-1210 and Apatinib & NCT03463876 & $\|$ & Advanced HCC patients & SHR 1210 + Apatinib & Active, not recruiting \\
\hline Camrelizumab and Apatinib & NCT04523662 & $\|$ & Advanced liver cancer patients & $\begin{array}{l}\text { Carrelizumab combined with } \\
\text { Apatinib Mesylate and } \\
\text { radiotherapy }\end{array}$ & Not yet recruiting \\
\hline Apatinib & NCT02329860 & III & $\begin{array}{l}\text { HCC patients after systemic } \\
\text { therapy }\end{array}$ & Apatinib or placebo & Completed \\
\hline Apatinib and TACE & NCT02702323 & $\|/\| \|$ & $\begin{array}{l}\text { Patients with pulmonary } \\
\text { metastasis of liver cancer }\end{array}$ & Apatinib combined with TACE & Unknown \\
\hline $\begin{array}{l}\text { Thermal Ablation, Apatinib } \\
\text { and Carilimub }\end{array}$ & NCT04204577 & $\|$ & Advanced liver cancer patients & $\begin{array}{l}\text { Thermal ablation combined } \\
\text { with Apatinib and Carilimub }\end{array}$ & Recruiting \\
\hline Apatinib & NCT03261791 & $\|$ & $\begin{array}{l}\text { HCC patients with PVTT who } \\
\text { underwent radical resection }\end{array}$ & Adjuvant therapy with Apatinib & Unknown \\
\hline SHR-1210 and Apatinib & NCT03764293 & III & Advanced HCC patients & $\begin{array}{l}\text { SHR-1210 in Combination With } \\
\text { Apatinib as first-line therapy vs. } \\
\text { Sorafenib }\end{array}$ & Recruiting \\
\hline
\end{tabular}

TABLE 4 | Ongoing clinical trials involving GPC3 in HCC.

\begin{tabular}{|c|c|c|c|c|c|}
\hline Name & Trail ID & Phase & Study population & Intervention & Status \\
\hline GC33 & japicCTI 101255 & 1 & HCC with no preferred treatment & GC33 & Unknown \\
\hline GPC3 CAR-T & NCT02395250 & 1 & GPC3 + HCC patients & GPC3 CAR-T cells & Completed \\
\hline GPC3 CAR-T & NCT02723942 & $|/| \mid$ & GPC3 + HCC patients & GPC3 CAR-T cells & Completed \\
\hline GPC3 CAR-T & NCT03084380 & $|/| I$ & GPC3 + HCC patients & Anti-GPC3 CAR-T cells & Unknown \\
\hline GLY CAR-T & NCT02905188 & I & $\begin{array}{l}\text { Unresectable, recurrent metastatic } \\
\text { GPC3 + HCC patients }\end{array}$ & GLYCAR T cells; Fludarabine & Recruiting \\
\hline GPC3 CAR-T & NCT03884751 & 1 & Late stage HCC patients, unresectable & GPC3 CAR-T cells & Recruiting \\
\hline GPC3-T2 CAR-T & NCT03198546 & I & GPC3 + advanced HCC patients & $\begin{array}{l}\text { GPC3 and/or TGF } \beta \text { targeting } \\
\text { CAR-T cells }\end{array}$ & Recruiting \\
\hline GPC3 CAR-T & NCT04506983 & 1 & $\begin{array}{l}\text { GPC3 + HCC patients after failure or } \\
\text { intolerance of first-line treatment }\end{array}$ & GPC3 CAR-T cells & Not yet recruiting \\
\hline GPC3 CAR-T & NCT03146234 & $\begin{array}{l}\text { Not } \\
\text { Applicable }\end{array}$ & $\begin{array}{l}\text { GPC3 + relapsed or refractory HCC } \\
\text { patients }\end{array}$ & GPC3 CAR-T cells & Completed \\
\hline GPC3 CAR-T & NCT04121273 & I & GPC3 + advanced HCC patients & GPC3 CAR-T cells & Recruiting \\
\hline GPC3 CAR-T & NCT03980288 & 1 & $\begin{array}{l}\text { Refractory or intolerant to current } \\
\text { standard systemic treatment, } \\
\text { GPC3 + advanced HCC patients }\end{array}$ & GPC3 CAR-T cells & Recruiting \\
\hline GPC3 CAR-T & NCT02715362 & $|/| \mid$ & $\begin{array}{l}\text { Unresectable, at least one prior } \\
\text { standard of care chemotherapy, } \\
\text { GPC3 + advanced HCC patients }\end{array}$ & TAI-GPC3 CART cells & Unknown \\
\hline GPC3 CAR-T & NCT03130712 & $|/| \mid$ & $\begin{array}{l}\text { GPC3 + advanced HCC patients with } \\
\text { one prior standard of chemotherapy or } \\
\text { surgery }\end{array}$ & GPC3 CART cells & Unknown \\
\hline CT0180 Cells & NCT04756648 & 1 & GPC3 + advanced HCC patients & $\begin{array}{l}\text { CT0180 humanized anti GPC3 } \\
\text { autogenous T cell injection }\end{array}$ & Not yet recruiting \\
\hline GPC3 CAR-T & NCT04121273 & I & GPC3 + advanced HCC patients & CAR-T cell immunotherapy & Recruiting \\
\hline $\begin{array}{l}\text { ECT204 T-Cell } \\
\text { therapy (ARYA3) }\end{array}$ & NCT04864054 & $|/| \mid$ & $\begin{array}{l}\text { GPC } 3 \text { + adults advanced HCC patients } \\
\text { with failure or intolerance of at least two } \\
\text { different anti-HCC systemic agents }\end{array}$ & ECT204 T cells & Not yet recruiting \\
\hline $\begin{array}{l}\text { GC33 } \\
(\mathrm{RO5} 137382)\end{array}$ & NCT01507168 & $\|$ & $\begin{array}{l}\text { Unresectable advanced or metastatic } \\
\text { GPC3 + HCC patients }\end{array}$ & GC33 & Completed \\
\hline GPC3 CAR-T & NCT02959151 & $|/| \mid$ & GPC3 + advanced liver malignancy & CAR-T cell & Unknown \\
\hline
\end{tabular}

clinical basis for further trials in advanced HCC (Zhu et al., 2013). However, grade 3 adverse events were shown as blood pressure increase, lymphocyte and platelet count decrease in two or more patients when the same agent was tested in Japan (Ikeda et al., 2014). Furthermore, a phase I clinical trial was performed on a GPC3 derived peptide vaccine (Table 5; Sawada et al., 2012). The peptide vaccine caused grade III hematologic adverse events (impaired liver function) in 4 out of 33 patients, although lymph node regression in $24 / 33$ patients and liver tumor disappearance in 2/33 patients were observed (Sawada et al., 2012). 
PF-03446962 is an activin receptor-like kinase-1 (ALK-1) monoclonal antibody. A phase I clinical trial had explored the safety, pharmacokinetics and antitumor activity of PF-03446962 in total of $24 \mathrm{HCC}$ patients. The most common treatmentrelated adverse events were thrombocytopenia (33.3\%), fatigue (29.2\%), shivering (16.7\%), fever epistaxis and anemia, and ENTassociated telangiectasia ( 2 patients). Based on the trial, the disease control rate was 29\% (Simonelli et al., 2016) and a phase II trial was suggested to have a dose of $7 \mathrm{mg} / \mathrm{kg}$ of PF-03446962 for single drug treatment of HCC patients.

Antibodies against PD-1 and its ligand PD-L1 have shown anti-tumor effects in many cancers including liver cancer (Apolo et al., 2017). SHR-1210 is an anti-PD-1 antibody and phase Ia and Ib clinical trials that combined SHR-1210 with apatinib (VEGFR2 inhibitor) for the treatment of advanced HCC, stomach and esophageal cancers were performed. Phase Ia was designed to identify the maximum tolerated dose (MTD) and the recommended phase II dose (RP2D) of SHR-1210 when combined with apatinib. The combination of SHR-1210 and apatinib showed controllable toxicity in HCC and GC/EGJC patients with recommended single dose. The RP2D of SHR-1210 in the apatinib combined treatment was $250 \mathrm{mg}$, demonstrating encouraging clinical activity in patients with advanced liver cancer. SHR-1210 combined with apatinib showed the objective response rate of $30.8 \%$ (95\% CI: $17.0-47.6 \%$ ) as observed in 39 patients. Of the 16 evaluable HCC patients, 8 patients obtained partial responses $(50.0 \%, 95 \%$ CI: $24.7-75.4 \%)$. The grade 3 adverse events observed are hypertension (15.2\%) and elevated aspartate aminotransferase (AAT, 15.2\%) (Xu et al., 2019). In brief, the combination of SHR-1210 and apatinib demonstrated encouraging results in patients with advanced liver cancer. Moreover, there are lots of ongoing clinical trials involving PD1 treatment in HCC as shown in Supplementary Table 1, which mostly explore the efficacy and safety of new drugs and new therapies of existing drugs on HCC. However, most of these clinical trials are in phase I/II without published results.

\section{SUMMARY AND FUTURE PERSPECTIVES}

Hepatocellular carcinoma is one of the most common and lethal tumors worldwide. Small molecule targeted drugs, such as sorafenib, have only about 3 months survival benefit due to drug resistance to cancer stem cells (Xin $\mathrm{H}$. W. et al., 2013). Therefore, further improvement of HCC therapy is urgent. Tumor immunotherapy has shown significant potential. GPC3 based HCC immunotherapies included GPC3/NK BsAb, GPC3/BiTE, GPC3/CAR-T, GPC3 mAb, and GPC3 peptide vaccine. These HCC immunotherapies have showed promising results in preclinical studies, ongoing phase I/II clinical trials and published phase I/II clinical trials. The published clinical trials demonstrated their preliminary safety and effectiveness, which warranted for their phase II trials in future. In addition, TLS11a aptamer-BiTE and EpCAM/BiTE showed their effectiveness in eliminating HCC tumors in mouse models. Anti-PD-1 antibody was also reported to suppress HCC progression in mouse xenograft and to be preliminarily safe and effective in clinical trials.

Nevertheless, most of the current specific antibodies applied in the HCC treatment are in preclinical experimental stage or early phase clinical trials. The antibodies that worked on animals may not work well on humans due to heterogeneity and complex immunogenicity, as different species have different immune rejection response and human body may produce rejection reaction to the animal source antibodies in different degree. Their effectiveness and safety need to be improved. The antibodies used in the immunotherapy had immunogenicity, poor stability,

TABLE 5 | Published clinical trials involving GPC3, ALK-1, and PD-1 in HCC immunotherapy.

\begin{tabular}{|c|c|c|c|c|c|c|c|}
\hline Drug & Combination & Route, dose & Enrollment & Efficacy & Adverse effect & Phase & Ref \\
\hline $\begin{array}{l}\text { GPC3 derived } \\
\text { peptide vaccine }\end{array}$ & None & $\begin{array}{l}\text { Intracutaneously, } \\
\text { on days } 1,15 \text { and } \\
29, \text { at doses } 0.3 \text {, } \\
1.0,3.0,10, \\
30 \mathrm{mg} / \text { body } \\
\text { surface area. }\end{array}$ & $\begin{array}{l}\text { Non-randomized, } \\
\text { open label }\end{array}$ & $\begin{array}{l}\text { 24/33 lymph node } \\
\text { regression, } 2 \text { liver } \\
\text { tumors } \\
\text { disappeared. }\end{array}$ & $\begin{array}{l}\text { Grade III } \\
\text { hematologic } \\
\text { adverse events } \\
\text { (impaired liver } \\
\text { function) in } 4 \\
\text { patients }\end{array}$ & I & $\begin{array}{l}\text { Sawada et al., } \\
2012\end{array}$ \\
\hline GC33 & $\begin{array}{l}75 \% \text { patients } \\
\text { received sorafenib }\end{array}$ & $\begin{array}{l}\text { Dose escalation, } \\
2.5-20 \mathrm{mg} / \mathrm{kg} \text {, } \\
\text { weekly i.v. }\end{array}$ & $\begin{array}{l}\text { Multicenter, open } \\
\text { label, single arm }\end{array}$ & $\begin{array}{l}\text { AFP levels } \\
\text { decreased or } \\
\text { stabilized }\end{array}$ & $\begin{array}{l}\text { Grade III, NK cell } \\
\text { numbers in plasma } \\
\text { decreased. }\end{array}$ & 1 & Zhu et al., 2013 \\
\hline $\begin{array}{l}\text { Anti-ALK-1 } \\
\text { McAb } \\
\text { PF-03446962 }\end{array}$ & $\begin{array}{l}\text { Antiangiogenic or } \\
\text { sorafenib therapy }\end{array}$ & $\begin{array}{l}1 \mathrm{~h} \text { iv on days } 1 \\
\text { and } 29 \text { and every } \\
2 \text { weeks thereafter, } \\
\text { RP2D of } 7 \mathrm{mg} / \mathrm{kg} \text {. }\end{array}$ & Single-arm & $\begin{array}{l}\text { Disease control rate } \\
\text { at } 12 \text { weeks was } \\
29 \% .\end{array}$ & $\begin{array}{l}\text { Grade III } \\
\text { Thrombocytopenia } \\
\text { in } 33 \% \text {, grade IV } \\
\text { abdominal pain in } 1 \\
\text { patient. }\end{array}$ & I & $\begin{array}{l}\text { Simonelli et al., } \\
2016\end{array}$ \\
\hline $\begin{array}{l}\text { SHR-1210, an } \\
\text { anti-PD-1 } \\
\text { McAb }\end{array}$ & $\begin{array}{l}\text { Apatinib, a VEGFR2 } \\
\text { Inhibitor }\end{array}$ & $\begin{array}{l}\text { Oral apatinib } \\
\text { once-daily } \\
\text { combined with } \\
\text { SHR-1210 } \\
\text { administered } \\
\text { intravenously every } \\
2 \text { weeks. }\end{array}$ & $\begin{array}{l}\text { Single center, open } \\
\text { label. }\end{array}$ & $\begin{array}{l}\text { Objective response } \\
\text { rate is } 30.8 \% \text {, } \\
\text { partial response is } \\
50 \% \text {. }\end{array}$ & $\begin{array}{l}\text { Grade III Lipases } \\
\text { rise }(6.7 \%), \\
\text { preumonitis (20\%) } \\
\text { Hypertension } \\
\text { (15.2\%), increased } \\
\text { AAT } 15.2 \% \text {. }\end{array}$ & $\mathrm{la}$ and $\mathrm{lb}$ & Xu et al., 2019 \\
\hline
\end{tabular}


and high cost, which may limit their clinical application. CAR$\mathrm{T}$ modification, in combination with the disruption of inhibitory immune checkpoints, represents a promising method of tumor immunotherapy. Moreover, the HCC immunotherapy has not achieved significant results in clinical trials and further effective approaches are needed to explore for HCC immunotherapy. In future, we suggest that dendritic cell (DC) based tumor immunotherapy may be studied in HCC, as DC-derived exons was found to be involved in antigen presentation during antitumor immune response, besides, DC is the most important monitoring sentinel cell in tumor microenvironment (Wang et al., 2020). Oncolytic viruses may also be applied for HCC tumor immunotherapy. It is superior to conventional tumor treatments due to a relatively shorter period of treatment, reduction of toxicity, as well as the possibility of targeting micro-metastases (Wu et al., 2018; Cai et al., 2020; Wang et al., 2020). Engineered viral envelope glycoproteins can specifically target tumors (Liu X. Q. et al., 2018) and the technology of clustered regularly interspaced short palindromic repeats/CRISPR-associated protein 9 (CRISPR/Cas9) genomic editing has prominently promoted the study of oncolytic viruses (Wang D. et al., 2018).

\section{REFERENCES}

Apolo, A. B., Infante, J. R., Balmanoukian, A., Patel, M. R., Wang, D., Kelly, K., et al. (2017). Avelumab, an anti-programmed death-ligand 1 antibody, in patients with refractory metastatic urothelial carcinoma: results from a multicenter, phase Ib study. J. Clin. Oncol. 35, 2117-2124. doi: 10.1200/jco.2016.71.6795

Baumhoer, D., Tornillo, L., Stadlmann, S., Roncalli, M., Diamantis, E. K., and Terracciano, L. M. (2008). Glypican 3 expression in human nonneoplastic, preneoplastic, and neoplastic tissues: a tissue microarray analysis of 4,387 tissue samples. Am. J. Clin. Pathol. 129, 899-906. doi: 10.1309/hcqwpwd50xhd2dw6

Bi, Y., Jiang, H., Wang, P., Song, B., Wang, H., Kong, X., et al. (2017). Treatment of hepatocellular carcinoma with a GPC3-targeted bispecific T cell engager. Oncotarget 8, 52866-52876. doi: 10.18632/oncotarget.17905

Boussiotis, V. A. (2016). Molecular and biochemical aspects of the PD-1 checkpoint pathway. N. Engl. J. Med. 375, 1767-1778. doi: 10.1056/nejmra1514296

Cai, W., Zeng, L., Wang, L., Wang, Y., Cheng, J., Zhang, Y., et al. (2020). The latest battles between EGFR monoclonal antibodies and resistant tumor cells. Front. Oncol. 10:1249. doi: 10.3389/fonc.2020.01249

Capurro, M. I., Xiang, Y. Y., Lobe, C., and Filmus, J. (2005). Glypican-3 promotes the growth of hepatocellular carcinoma by stimulating canonical Wnt signaling. Cancer Res. 65, 6245-6254. doi: 10.1158/0008-5472.can-04-4244

Carpenter, B., Lin, Y., Stoll, S., Raffai, R. L., McCuskey, R., and Wang, R. (2005). VEGF is crucial for the hepatic vascular development required for lipoprotein uptake. Development 132, 3293-3303. doi: 10.1242/dev.01902

Chang, B., Shen, L., Wang, K., Jin, J., Huang, T., Chen, Q., et al. (2018). High number of PD-1 positive intratumoural lymphocytes predicts survival benefit of cytokine-induced killer cells for hepatocellular carcinoma patients. Liver Int. 38, 1449-1458. doi: 10.1111/liv.13697

Chen, G., Chen, Y. C., Reis, B., Belousov, A., Jukofsky, L., Rossin, C., et al. (2018). Combining expression of GPC3 in tumors and CD16 on NK cells from peripheral blood to identify patients responding to codrituzumab. Oncotarget 9, 10436-10444. doi: 10.18632/oncotarget.23830

Chen, T., Dai, X., Dai, J., Ding, C., Zhang, Z., Lin, Z., et al. (2020). AFP promotes HCC progression by suppressing the HuR-mediated Fas/FADD apoptotic pathway. Cell Death Dis. 11:822.

Cheng, W., Tseng, C. J., Lin, T. T., Cheng, I., Pan, H. W., Hsu, H. C., et al. (2008). Glypican-3-mediated oncogenesis involves the Insulin-like growth factor-signaling pathway. Carcinogenesis 29, 1319-1326. doi: 10.1093/carcin/ bgn091

\section{AUTHOR CONTRIBUTIONS}

S-LH, L-MY, and H-WX designed this research. S-LH contributed to literature search and drafted the manuscript. S-LH, Y-MW, Q-YW, G-GF, F-QW, L-MY, X-HZ, and H-WX revised and edited the manuscript. L-MY, X-HZ, and $\mathrm{H}-\mathrm{WX}$ approved the final version of the manuscript. All authors contributed to the article and approved the submitted version.

\section{FUNDING}

This work was partly supported by the National Natural Science Foundation of China (81872412).

\section{SUPPLEMENTARY MATERIAL}

The Supplementary Material for this article can be found online at: https://www.frontiersin.org/articles/10.3389/fgene. 2021.691391/full\#supplementary-material

Dai, W., Wang, Y., Yang, T., Wang, J., Wu, W., and Gu, J. (2019). Downregulation of exosomal CLEC3B in hepatocellular carcinoma promotes metastasis and angiogenesis via AMPK and VEGF signals. Cell Commun. Signal. 17:113.

De Angelis, M. L., Francescangeli, F., La Torre, F., and Zeuner, A. (2019). Stem cell plasticity and dormancy in the development of cancer therapy resistance. Front. Oncol. 9:626. doi: 10.3389/fonc.2019.00626

De Luca, E., Marino, D., and Di Maio, M. (2020). Ramucirumab, a second-line option for patients with hepatocellular carcinoma: a review of the evidence. Cancer Manag. Res. 12, 3721-3729. doi: 10.2147/cmar.s216220

Ellison, L. M., Man, Y., Stojadinovic, A., Xin, H., and Avital, I. (2017). Cytoreductive surgery and hyperthermic intraperitoneal chemotherapy in treatment of gastric cancer with peritoneal carcinomatosis. Chin. J. Cancer Res. 29, 86-92.

El-Saadany, S., El-Demerdash, T., Helmy, A., Mayah, W. W., El-Sayed, H. B., Hassanien, M., et al. (2018). Diagnostic value of Glypican-3 for hepatocellular carcinomas. Asian Pac. J. Cancer Prev. 19, 811-817.

Feng, D., Hui, X., Shi-Chun, L., Yan-Hua, B., Li, C., Xiao-Hui, L., et al. (2017). Initial experience of anti-PD1 therapy with nivolumab in advanced hepatocellular carcinoma. Oncotarget 8, 96649-96655. doi: 10.18632/ oncotarget.20029

Filmus, J., and Selleck, S. B. (2001). Glypicans: proteoglycans with a surprise. Clin. Invest. 108, 497-501. doi: 10.1172/jci200113712

Finkelmeier, F., Canli, O., Tal, A., Pleli, T., Trojan, J., Schmidt, M., et al. (2016). High levels of the soluble programmed death-ligand (sPD-L1) identify hepatocellular carcinoma patients with a poor prognosis. Eur. J. Cancer 59, 152-159. doi: 10.1016/j.ejca.2016.03.002

Finn, R. S., Ryoo, B. Y., Merle, P., Kudo, M., Bouattour, M., Lim, H. Y., et al. (2020a). Pembrolizumab as second-line therapy in patients with advanced hepatocellular carcinoma in KEYNOTE-240: a randomized, double-blind, phase iii trial. J. Clin. Oncol. 38, 193-202. doi: 10.1200/jco.19.01307

Finn, R. S., Qin, S., Ikeda, M., Galle, P. R., Ducreux, M., Kim, T., et al. (2020b). Atezolizumab plus bevacizumab in unresectable hepatocellular carcinoma. N. Engl. J. Med. 382, 1894-1905.

Frankel, S. R., and Baeuerle, P. A. (2013). Targeting T cells to tumor cells using bispecific antibodies. Curr. Opin. Chem. Biol. 17, 385-392. doi: 10.1016/j.cbpa. 2013.03.029

Gros, A., Robbins, P. F., Yao, X., Li, Y. F., Turcotte, S., Tran, E., et al. (2014). PD1 identifies the patient-specific CD8(+) tumor-reactive repertoire infiltrating human tumors. J. Clin. Invest. 124, 2246-2259. doi: 10.1172/jci73639 
Guo, X., Jiang, H., Shi, B., Zhou, M., Zhang, H., Shi, Z., et al. (2018). Disruption of PD-1 enhanced the anti-tumor activity of chimeric antigen receptor $\mathrm{T}$ cells against hepatocellular carcinoma. Front. Pharmacol. 9:1118. doi: 10.3389/fphar. 2018.01118

Hack, S. P., Spahn, J., Chen, M., Cheng, A., Kaseb, A., Kudo, M., et al. (2020). IMbrave 050: a phase III trial of atezolizumab plus bevacizumab in high-risk hepatocellular carcinoma after curative resection or ablation. Future Oncol. 16, 975-989. doi: 10.2217/fon-2020-0162

Hari, D., Xin, H., Jaiswal, K., Wiegand, G., Kim, B., Ambe, C., et al. (2011). Isolation of live label-retaining cells and cells undergoing asymmetric cell division via nonrandom chromosomal cosegregation from human cancers. Stem Cells Dev. 20, 1649-1658. doi: 10.1089/scd.2010.0455

Ho, M., and Kim, H. (2011). Glypican-3: a new target for cancer immunotherapy. Eur. J. Cancer 47, 333-338. doi: 10.1016/j.ejca.2010.10.024

Hu, J., Li, P., Song, Y., Ge, Y. X., Meng, X. M., Huang, C., et al. (2018). Progress and prospects of circular RNAs in hepatocellular carcinoma: novel insights into their function. J. Cell Physiol. 233, 4408-4422. doi: 10.1002/jcp.26154

Hu, Z., He, J., Gong, W., Zhou, N., Zhou, S., Lai, Z., et al. (2018). TLS1la Aptamer/CD3 antibody anti-tumor system for liver cancer. J. Biomed. Nanotechnol. 14, 1645-1653. doi: 10.1166/jbn.2018.2619

Huang, K., Sun, B., Luo, N., Guo, H., Hu, J., and Peng, J. (2018). Programmed Death Receptor 1 (PD1) knockout and Human Telomerase Reverse Transcriptase (hTERT) transduction can enhance persistence and antitumor efficacy of cytokine-induced killer cells against hepatocellular carcinoma. Med. Sci. Monit. 24, 4573-4582. doi: 10.12659/msm.910903

Ikeda, M., Ohkawa, S., Okusaka, T., Mitsunaga, S., Kobayashi, S., Morizane, C., et al. (2014). Japanese phase I study of GC33, a humanized antibody against glypican-3 for advanced hepatocellular carcinoma. Cancer Sci. 105, 455-462. doi: $10.1111 /$ cas. 12368

Jin, L., He, Y., Tang, S., and Huang, S. (2018). LncRNA GHET1 predicts poor prognosis in hepatocellular carcinoma and promotes cell proliferation by silencing KLF2. J. Cell Physiol. 233, 4726-4734. doi: 10.1002/jcp.26257

Kimura, O., Kondo, Y., Kogure, T., Kakazu, E., Ninomiya, M., Iwata, T., et al. (2014). Expression of EpCAM increases in the hepatitis B related and the treatment-resistant hepatocellular carcinoma. Biomed. Res. Int. 2014:172913.

Kudo, M., Galle, P. R., Llovet, J. M., Finn, R. S., Vogel, A., Motomura, K., et al. (2020). Ramucirumab in elderly patients with hepatocellular carcinoma and elevated alpha-fetoprotein after sorafenib in REACH and REACH-2. Liver Int. 40, 2008-2020. doi: 10.1111/liv.14462

Kumar Kulabhusan, P., Hussain, B., and Yüce, M. (2020). Current perspectives on aptamers as diagnostic tools and therapeutic agents. Pharmaceutics 12:646. doi: 10.3390/pharmaceutics12070646

Lampen, M. H., Uchtenhagen, H., Blom, K., Varnaite, R., Pakalniene, J., Dailidyte, L., et al. (2018). Breadth and dynamics of HLA-A2- and HLA-B7-Restricted CD8(+) $\mathrm{T}$ cell responses against nonstructural viral proteins in acute human tick-borne encephalitis virus infection. Immunohorizons 2, 172-184. doi: 10. 4049/immunohorizons.1800029

Lepourcelet, M., Chen, Y. N., France, D. S., Wang, H., Crews, P., Petersen, F., et al. (2004). Small-molecule antagonists of the oncogenic Tcf/beta-catenin protein complex. Cancer Cell 5, 91-102. doi: 10.1016/s1535-6108(03)00334-9

Li, N., Wei, L., Liu, X., Bai, H., Ye, Y., Li, D., et al. (2019). A frizzledlike cysteine-rich domain in glypican-3 mediates Wnt binding and regulates hepatocellular carcinoma tumor growth in mice. Hepatology 70, 1231-1245. doi: 10.1002/hep.30646

Li, Y., Farmer, R. W., Yang, Y., and Martin, R. C. G. (2016). Epithelial cell adhesion molecule in human hepatocellular carcinoma cell lines: a target of chemoresistence. BMC Cancer 16:228. doi: 10.1186/s12885-016-2252-y

Li, Z., Li, N., Li, F., Zhou, Z., Sang, J., Chen, Y., et al. (2016). Immune checkpoint proteins PD-1 and TIM-3 are both highly expressed in liver tissues and correlate with their gene polymorphisms in patients with HBV-related hepatocellular carcinoma. Medicine 95:e5749. doi: 10.1097/md.0000000000005749

Lipovšek, D., Carvajal, I., Allentoff, A. J., Barros, A., Brailsford, J., Cong, Q., et al. (2018). Adnectin-drug conjugates for Glypican-3-specific delivery of a cytotoxic payload to tumors. Protein Eng. Des. Sel. 31, 159-171. doi: 10.1093/ protein/gzy013

Liu, H., Yang, C., Lu, W., and Zeng, Y. (2018). Prognostic significance of glypican3 expression in hepatocellular carcinoma: a meta-analysis. Medicine 97:e9702. doi: $10.1097 / \mathrm{md} .0000000000009702$
Liu, S., Li, Y., Chen, W., Zheng, P., Liu, T., He, W., et al. (2012). Silencing glypican-3 expression induces apoptosis in human hepatocellular carcinoma cells. Biochem. Biophys. Res. Commun. 419, 656-661. doi: 10.1016/j.bbrc.2012. 02.069

Liu, X. Q., Xin, H. Y., Lyu, Y. N., Ma, Z. W., Peng, X. C., Xiang, Y., et al. (2018). Oncolytic herpes simplex virus tumor targeting and neutralization escape by engineering viral envelope glycoproteins. Drug Deliv. 25, 1950-1962. doi: 10. 1080/10717544.2018.1534895

Liu, Y., Qiao, Y., Hu, C., Liu, L., Zhou, L., Liu, B., et al. (2016). VEGFR2 inhibition by RNA interference affects cell proliferation, migration, invasion, and response to radiation in Calu-1 cells. Clin. Transl. Oncol. 18, 212-219. doi: 10.1007/ s12094-015-1358-Z

Liu, Y., Yu, C., Wu, Y., Sun, X., Su, Q., You, C., et al. (2017). CD44(+) fibroblasts increases breast cancer cell survival and drug resistance via IGF2BP3-CD44-IGF2 signalling. J. Cell Mol. Med. 21, 1979-1988. doi: $10.1111 /$ jcmm. 13118

Liu, Z., Zhu, L., Liu, J., Pu, Z., Ruan, Z., and Chen, J. (2020). Vascular endothelial growth factor receptor- 2 and its association with tumor immune regulatory gene expression in hepatocellular carcinoma. Aging 12, 25172-25188. doi: 10.18632/aging.104119

Llovet, J. M., Chen, Y., Wurmbach, E., Roayaie, S., Fiel, M. I., Schwartz, M., et al. (2006). A molecular signature to discriminate dysplastic nodules from early hepatocellular carcinoma in HCV cirrhosis. Gastroenterology 131, 1758-1767. doi: 10.1053/j.gastro.2006.09.014

Midorikawa, Y., Ishikawa, S., Iwanari, H., Imamura, T., Sakamoto, H., Miyazono, K., et al. (2003). Glypican-3, overexpressed in hepatocellular carcinoma, modulates FGF2 and BMP-7 signaling. Int. J. Cancer 103, 455-465. doi: 10. 1002/ijc. 10856

Minata, M., Harada, K. H., Kudo, M., Ikai, I., and Nishida, N. (2013). The prognostic value of vascular endothelial growth factor in hepatocellular carcinoma for predicting metastasis after curative resection. Oncology 84(Suppl. 1), 75-81. doi: 10.1159/000345894

Oberst, M. D., Fuhrmann, S., Mulgrew, K., Amann, M., Cheng, L., Lutterbuese, P., et al. (2014). CEA/CD3 bispecific antibody MEDI-565/AMG 211 activation of $\mathrm{T}$ cells and subsequent killing of human tumors is independent of mutations commonly found in colorectal adenocarcinomas. Mabs 6, 1571-1584. doi: $10.4161 / 19420862.2014 .975660$

Ofuji, K., Saito, K., Suzuki, S., Shimomura, M., Shirakawa, H., Nobuoka, D., et al. (2017). Perioperative plasma glypican-3 level may enable prediction of the risk of recurrence after surgery in patients with stage I hepatocellular carcinoma. Oncotarget 8, 37835-37844. doi: 10.18632/oncotarget.14271

Ohaegbulam, K. C., Assal, A., Lazar-Molnar, E., Yao, Y., and Zang, X. (2015). Human cancer immunotherapy with antibodies to the PD-1 and PD-L1 pathway. Trends Mol. Med. 21, 24-33.

Pandit, H., Li, Y., Li, X., Zhang, W., Li, S., and Martin, R. (2018). Enrichment of cancer stem cells via beta-catenin contributing to the tumorigenesis of hepatocellular carcinoma. BMC Cancer 18:783. doi: 10.1186/s12885-018-4683-0

Park, D. J., Sung, P. S., Kim, J. H., Lee, G. W., Jang, J. W., Jung, E. S., et al. (2020). EpCAM-high liver cancer stem cells resist natural killer cell-mediated cytotoxicity by upregulating CEACAM1. J. Immunother. Cancer 8:e000301. doi: 10.1136/jitc-2019-000301

Ruiz De Galarreta, M., Bresnahan, E., Molina-Sánchez, P., Lindblad, K. E., Maier, B., Sia, D., et al. (2019). $\beta$-Catenin activation promotes immune escape and resistance to Anti-PD-1 therapy in hepatocellular carcinoma. Cancer Discov. 9, 1124-1141. doi: 10.1158/2159-8290.cd-19-0074

Sawada, Y., Yoshikawa, T., Nobuoka, D., Shirakawa, H., Kuronuma, T., Motomura, Y., et al. (2012). Phase I trial of a glypican-3-derived peptide vaccine for advanced hepatocellular carcinoma: immunologic evidence and potential for improving overall survival. Clin. Cancer Res. 18, 3686-3696. doi: 10.1158/10780432.ccr-11-3044

Sawada, Y., Yoshikawa, T., Ofuji, K., Yoshimura, M., Tsuchiya, N., Takahashi, M., et al. (2016). Phase II study of the GPC3-derived peptide vaccine as an adjuvant therapy for hepatocellular carcinoma patients. Oncoimmunology 5:e1129483. doi: 10.1080/2162402x.2015.1129483

Schmelzer, E., Wauthier, E., and Reid, L. M. (2006). The phenotypes of pluripotent human hepatic progenitors. Stem Cells 24, 1852-1858. doi: 10.1634/stemcells. 2006-0036 
Sedykh, S. E., Prinz, V. V., Buneva, V. N., and Nevinsky, G. A. (2018). Bispecific antibodies: design, therapy, perspectives. Drug Des. Dev. Ther. 12, 195-208. doi: $10.2147 /$ dddt.s151282

Sharma, A., Seow, J., Dutertre, C. A., Pai, R., Bleriot, C., Mishra, A., et al. (2020). Onco-fetal reprogramming of endothelial cells drives immunosuppressive macrophages in hepatocellular carcinoma. Cell 183, 377-394.e21.

Simonelli, M., Zucali, P., Santoro, A., Thomas, M. B., de Braud, F. G., Borghaei, H., et al. (2016). Phase I study of PF-03446962, a fully human monoclonal antibody against activin receptor-like kinase-1, in patients with hepatocellular carcinoma. Ann. Oncol. 27, 1782-1787. doi: 10.1093/annonc/mdw240

Song, J., Guan, Z., Song, C., Li, M., Gao, Z., and Zhao, Y. (2021). Apatinib suppresses the migration, invasion and angiogenesis of hepatocellular carcinoma cells by blocking VEGF and PI3K/AKT signaling pathways. Mol. Med. Rep. 23:429.

Su, M., Zhao, Y., and Liu, J. (2018). The role of definitive local treatment in metastatic hepatocellular carcinoma patients: a SEER-based study. Medicine 97:e0020. doi: 10.1097/md.0000000000010020

Sun, B., Huang, Z., Wang, B., Yu, Y., Lin, S., Luo, L., et al. (2017). Significance of Glypican-3 (GPC3) expression in hepatocellular cancer diagnosis. Med. Sci. Monit. 23, 850-855. doi: 10.12659/msm.899198

Takai, H., Ashihara, M., Ishiguro, T., Terashima, H., Watanabe, T., Kato, A., et al. (2009). Involvement of glypican-3 in the recruitment of M2-polarized tumor-associated macrophages in hepatocellular carcinoma. Cancer. Ther. 8, 2329-2338. doi: 10.4161/cbt.8.24.9985

Tian, S., Quan, H., Xie, C., Guo, H., Lu, F., Xu, Y., et al. (2011). YN968D1 is a novel and selective inhibitor of vascular endothelial growth factor receptor-2 tyrosine kinase with potent activity in vitro and in vivo. Cancer Sci. 102, 1374-1380. doi: 10.1111/j.1349-7006.2011.01939.x

Wang, D., Wang, X. W., Peng, X. C., Xiang, Y., Song, S. B., Wang, Y. Y., et al. (2018). CRISPR/Cas9 genome editing technology significantly accelerated herpes simplex virus research. Cancer Gene Ther. 25, 93-105. doi: 10.1038/ s41417-018-0016-3

Wang, Q., Liu, F., and Liu, L. (2017). Prognostic significance of PD-L1 in solid tumor: an updated meta-analysis. Medicine 96:e6369. doi: 10.1097/md. 0000000000006369

Wang, Y., Liu, J., Pan, H., Xing, J., Wu, X., Li, Q., et al. (2018). A GPC3-targeting bispecific antibody, GPC3-S-Fab, with potent cytotoxicity. J. Vis. Exp. 12:57588.

Wang, Y., Xiang, Y., Xin, V. W., Wang, X., Peng, X., Liu, X., et al. (2020). Dendritic cell biology and its role in tumor immunotherapy. J. Hematol. Oncol. 13:107.

Wu, Z. J., Tang, F. R., Ma, Z. W., Peng, X. C., Xiang, Y., Zhang, Y., et al. (2018). Oncolytic viruses for tumor precision imaging and radiotherapy. Hum. Gene Ther. 29, 204-222. doi: 10.1089/hum.2017.189

Xiang, Q. F., Zhang, D. M., Wang, J. N., Zhang, H. W., Zheng, Z. Y., Yu, D. C., et al. (2015). Cabozantinib reverses multidrug resistance of human hepatoma HepG2/adr cells by modulating the function of P-glycoprotein. Liver Int. 35, 1010-1023. doi: 10.1111/liv.12524

Xin, H., Ambe, C. M., Ray, S., Kim, B., Koizumi, T., Wiegand, G. W., et al. (2013). Wnt and the cancer niche: paracrine interactions with gastrointestinal cancer cells undergoing asymmetric cell division. J. Cancer 4, 447-457. doi: $10.7150 /$ jca. 6896

Xin, H. W., Ambe, C. M., Hari, D. M., Wiegand, G. W., Miller, T. C., Chen, J. Q., et al. (2013). Label-retaining liver cancer cells are relatively resistant to sorafenib. Gut 62, 1777-1786. doi: 10.1136/gutjnl-2012-303261

Xin, H. W., Ambe, C. M., Miller, T. C., Chen, J. Q., Wiegand, G. W., Anderson, A. J., et al. (2016). Liver label retaining cancer cells are relatively resistant to the reported anti-cancer stem cell drug metformin. J. Cancer 7, 1142-1151. doi: $10.7150 /$ jca. 10047
Xin, H., Hari, D. M., Mullinax, J. E., Ambe, C. M., Koizumi, T., Ray, S., et al. (2012). Tumor-initiating label-retaining cancer cells in human gastrointestinal cancers undergo asymmetric cell division. Stem Cells 30, 591-598. doi: 10.1002/stem. 1061

Xu, J., Zhang, Y., Jia, R., Yue, C., Chang, L., Liu, R., et al. (2019). Anti-PD1 antibody SHR-1210 combined with apatinib for advanced hepatocellular carcinoma, gastric, or esophagogastric junction cancer: an open-label, dose escalation and expansion study. Clin. Cancer Res. 25, 515-523. doi: 10.1158/ 1078-0432.ccr-18-2484

Yamashita, T., and Wang, X. W. (2013). Cancer stem cells in the development of liver cancer. J. Clin. Invest. 123, 1911-1918.

Yamashita, T., Budhu, A., Forgues, M., and Wang, X. W. (2007). Activation of hepatic stem cell marker EpCAM by Wnt-beta-catenin signaling in hepatocellular carcinoma. Cancer Res. 67, 10831-10839. doi: 10.1158/00085472.can-07-0908

Yamashita, T., Ji, J., Budhu, A., Forgues, M., Yang, W., Wang, H. Y., et al. (2009). EpCAM-positive hepatocellular carcinoma cells are tumor-initiating cells with stem/progenitor cell features. Gastroenterology 136, 1012-1024. doi: 10.1053/j. gastro.2008.12.004

Yang, X., Zhang, X. F., Lu, X., Jia, H. L., Liang, L., Dong, Q. Z., et al. (2014). MicroRNA-26a suppresses angiogenesis in human hepatocellular carcinoma by targeting hepatocyte growth factor-cMet pathway. Hepatology 59, 1874-1885. doi: 10.1002/hep.26941

Zhang, P., Shi, B., Gao, H., Jiang, H., Kong, J., Yan, J., et al. (2014). An EpCAM/CD3 bispecific antibody efficiently eliminates hepatocellular carcinoma cells with limited galectin-1 expression. Cancer Immunol. Immunother. 63, 121-132. doi: 10.1007/s00262-013-1497-4

Zhang, Z. B., Shi, Z., Yang, L. F., and Gao, H. B. (2020). Caveolin-1 knockdown decreases SMMC7721 human hepatocellular carcinoma cell invasiveness by inhibiting vascular endothelial growth factor-induced angiogenesis. Can. J. Gastroenterol. Hepatol. 2020:8880888.

Zhou, B., Yan, J., Guo, L., Zhang, B., Liu, S., Yu, M., et al. (2020). Hepatoma cellintrinsic TLR9 activation induces immune escape through PD-L1 upregulation in hepatocellular carcinoma. Theranostics 10, 6530-6543. doi: 10.7150/thno. 44417

Zhu, A. X., Gold, P. J., El-Khoueiry, A. B., Abrams, T. A., Morikawa, H., Ohishi, N., et al. (2013). First-in-man phase i study of GC33, a novel recombinant humanized antibody against Glypican-3, in patients with advanced hepatocellular carcinoma. Clin. Cancer Res. 19, 920-928. doi: 10. 1158/1078-0432.ccr-12-2616

Zhu, H., Jain, R. K., and Baxter, L. T. (1998). Tumor pretargeting for radioimmunodetection and radioimmunotherapy. J. Nucl. Med. 39, 65-76.

Zou, W., Wolchok, J. D., and Chen, L. (2016). PD-L1 (B7-H1) and PD-1 pathway blockade for cancer therapy: mechanisms, response biomarkers, and combinations. Sci. Transl. Med. 8:328rv4. doi: 10.1126/scitranslmed.aad7118

Conflict of Interest: The authors declare that the research was conducted in the absence of any commercial or financial relationships that could be construed as a potential conflict of interest.

Copyright (c) 2021 Huang, Wang, Wang, Feng, Wu, Yang, Zhang and Xin. This is an open-access article distributed under the terms of the Creative Commons Attribution License (CC BY). The use, distribution or reproduction in other forums is permitted, provided the original author(s) and the copyright owner(s) are credited and that the original publication in this journal is cited, in accordance with accepted academic practice. No use, distribution or reproduction is permitted which does not comply with these terms. 